\title{
Characterization of chemical processes involved in ozone depletion
}

\author{
Enim Enim Asira \\ Department of Chemistry, College of Education, Akamkpa, Cross River State, Nigeri- \\ The earth's carrying capacity to support human life has been ove reto by incre sing need
}

ABSTRACT to meet food requirements, consumption of resources; amount of aste gener in a d choice of technologies. These activities release into the atmosphere, ch cal const nts of varied concentrations. When these chemicals enter into the atmo on re, th are subjected to various transformations that yield products or intermediates that ter alter atmo vic chemical balance. In recent years, the global problem of ozone depletion 1 as underscored the danger of overstepping earth's ability to absorb waste products. This study erefore, focuses on the various chemical reactions involved in ozone depletion and the effects ozone laye depletion on plant, animals, materials and climate.

Keywords: Atmosphere; ozone; depletion; proce. esm crects

\section{INTRODUCTION}

It takes no stre of imagin to see that human species are agents of earth proportion. In our fort nake the earth yield more food for ourselves, we constantly diminish earth's Mity to su Jife of all kinds. The earth's capacity to support humans is determined by our $n$ sst basic $t$ od requirements, levels of consumption of resources, by the amount of a gerate technology choices and our success at mobilizing to deal with major threats.

ear abi ty to abs ib waste products is ozone depletion on daily basis, waste products are
cons out on arth. Some of these waste products destroy the ozone layer.

Ozo, is a triatomic molecule which is blue in colour and has a characteristic pungent smell. Under average condition, at ground level, each $\mathrm{cm}$ of air contains about $0.1 \%$ of ozone (Santra 2012). It occurs in significant amount $(710 \mathrm{ppm})$ in the lower stratosphere. High level of ozone is generally observed during hot, still sunny, weather where air mass has previously collected emission of hydrocarbons $\left(\mathrm{NO}_{\mathrm{x}}\right)$.

Ozone destructions are also dependent on geographical locations. For example, $4 \%$ of ozone destruction is in the tropics, $9 \%$ in the temperate zones and $14 \%$ in the Polar Regions (Bhatia, 2006). The decrease in rainfall level and increasing draughts in the world indicate that ozone depletion and global warming has taken place. 
The aim of this study is focus on the characterization chemical processes involved in ozone layer depletion. The specific objective is to explain the various effects of ozone layer depletion on humans, plants, materials and animals.

\section{FORMATION OF OZONE}

The formation of ozone in the troposphere is contributed by two sources:

A) Downward movement from the stratosphere

B) Direct photochemical production within the troposphere

\section{1. Downward Movement}

The $\mathrm{NO}_{\mathrm{x}}$ from stratosphere abstract energy in the UV radiation range $430 \mathrm{~h}$, rom the sun light and dissociated to give $\mathrm{NO}$ and reactive oxygen atom $\mathrm{O} \quad \mathrm{Vb}$ reacti oxygen atom then reacts with oxygen gas at the troposphere to produce $g$ one mo

$\mathrm{NO}_{2}{ }^{*}+\mathrm{hv}=\mathrm{NO}^{*}+\mathrm{O}^{*}$

$\mathrm{O}^{*}+\mathrm{O}_{2} \mathrm{tm}=\mathrm{O}_{3}+\mathrm{m}$

\section{DIRECT PHOTO CHEMICAL PRO 'TTION L LONE}

Above $50 \mathrm{~cm}(60-80 \mathrm{~cm})$, molecule $(\mathrm{v}$ en, $>2$ absorbs energy at $<240 \mathrm{~nm}$, and dissociates to form atomic oxygen
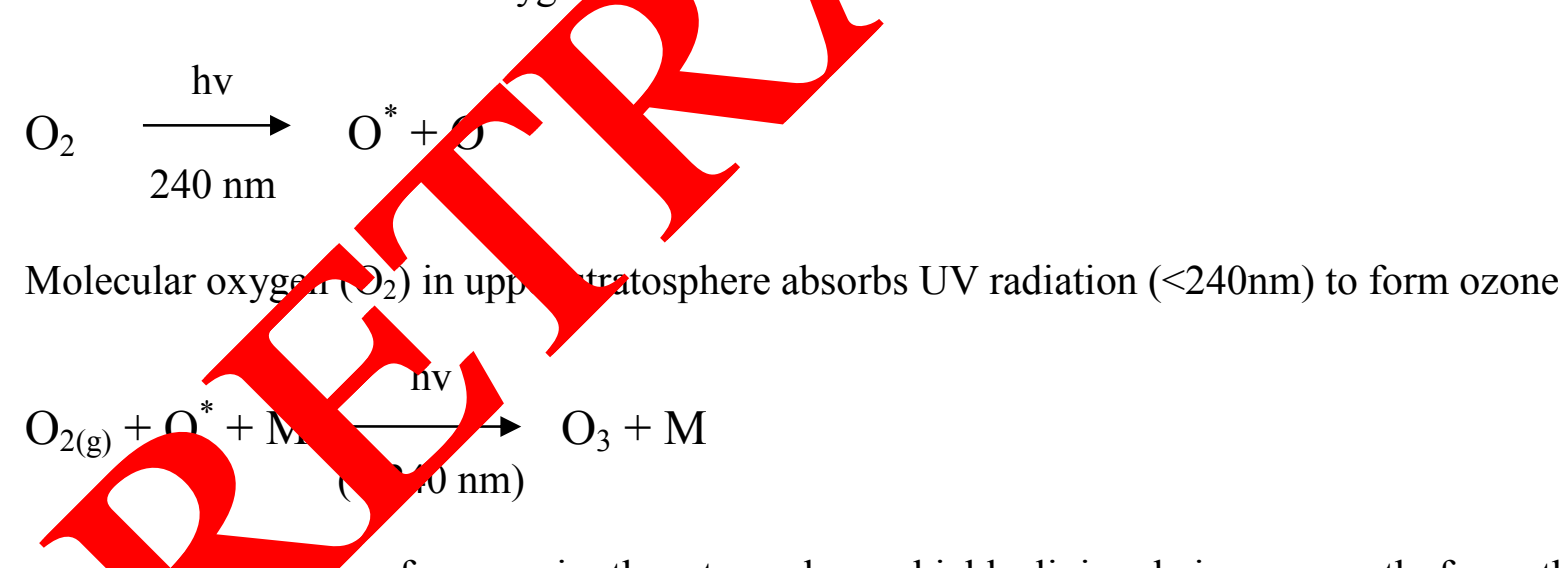
ecologic armful effects.

High evel of ozone destroys rubber due to its weak 0-0 bond and affects bronchial function and $\mathrm{w}$ toxic to plant and vegetation due to production of harmful intermediates (oxidants). 


\section{OZONE DEPLETION CHEMICAL PROCESSES}

Ozone depletion is simply the destruction of ozone layer in the stratosphere. The relative concentration of $\mathrm{NO}_{2}$ and $\mathrm{O}_{3}$ determine whether the destruction or generation of ozone takes place (Naranyanan, 2009).

In general, there are three principal ways of ozone $\left(\mathrm{O}_{3}\right)$ depletion:

- $\quad$ Hydrogen system (OH System)

- $\quad$ Nitrogen system $\left(\mathrm{NO}_{2}\right.$ system)

- $\quad$ Chlorine system $\left(\mathrm{CFCl}_{3} \mathrm{~W} \mathrm{CF}_{2} \mathrm{Cl}_{2}\right.$ system $)$

\section{OH SYSTEM}

This system destroys only $10 \%$ of $\mathrm{O}_{3}$ and the reaction earth crust. Water vapour in the atmosphere react with the 0 photochemical dissociation to yield hydroxyl group. The hy rox in turn, rects with ozone to form water and oxygen molecule.

$$
\begin{aligned}
& \mathrm{H}_{2} \mathrm{O}_{(\mathrm{g})}+\mathrm{O}^{*}(\mathrm{ID})=2 \mathrm{OH} \\
& { }^{*} \mathrm{OH}+\mathrm{O}_{3}=\mathrm{HO}_{2}{ }^{*}+\mathrm{O}_{2(\mathrm{~g})} \\
& \mathrm{H}_{2} \mathrm{O}_{(\mathrm{g})}+3 \mathrm{O}^{*}=2{ }^{*} \mathrm{OH}+\mathrm{O}_{2}
\end{aligned}
$$

Net: $\quad \mathrm{O}^{*}+\mathrm{O}_{3}=2 \mathrm{O}_{2(\mathrm{~g})}$

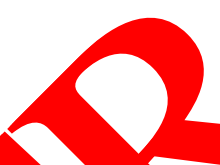

This can as well be form a from od tion of methane $\left(\mathrm{CH}_{4}\right)$.

\section{NITROG STEI (NO $\mathrm{NO}_{2}$ SYSTEM)}

Six, percen, one destruction occurs through $\mathrm{N}_{2} \mathrm{O}$ system. The $\mathrm{N}_{2} \mathrm{O}$ produced by ba ial a tion of phicro organism in ocean and soil (denitrification) diffuses upwards from tropos, re to suatosphere where its reacts with $\mathrm{O}^{*}$ in the presence of light to produce NO, which th restroys ozone. The detailed reaction is expressed below:

$$
\begin{aligned}
& \mathrm{NO}_{2}+\mathrm{O}^{*}(\mathrm{ID})=2 \mathrm{NO}^{*} \\
& \mathrm{~N}_{2} \mathrm{O}+\mathrm{O}^{*}(\mathrm{hv})=\mathrm{N}_{2}+\mathrm{O}_{2} \\
& \mathrm{NO}^{*}+\mathrm{O}_{3}=\mathrm{NO}_{2}{ }^{*}+\mathrm{O}_{2}
\end{aligned}
$$




$$
\mathrm{NO}_{2}+\mathrm{O}^{*}=\mathrm{NO}^{*}+\mathrm{O}_{2}
$$

Net: $\quad \mathrm{O}_{3}+\mathrm{O}=2 \mathrm{O}_{2}$

\section{CHLORINE SYSTEM ( $\mathrm{CFCl}_{3}$ or $\mathrm{CF}_{2} \mathrm{Cl}_{2}$ SYSTEM)}

Neutral chlorine contributes only very little to ozone destruction. The main sources of chloro species are chloro fluoro carbons, (CFCs) from fire extinguisher, per air conditioners, aluminum industries and plants that produce rubber. These compo inds are it in the troposphere but become disassociated in stratosphere.

$$
\begin{aligned}
& \mathrm{CFCl}_{3}+\mathrm{CF}_{2} \mathrm{Cl}_{2} \stackrel{\mathrm{hv}}{180-220} \\
& \mathrm{Cl}_{2} \stackrel{\mathrm{hv}}{\longrightarrow} \mathrm{Cl}^{*}+\mathrm{Cl}^{*} \\
& \mathrm{Cl}^{*}+\mathrm{O}_{3}=\mathrm{ClO}^{*}+\mathrm{O}_{2(\mathrm{~g})} \\
& \mathrm{ClO}^{*}+\mathrm{O}^{*}=\mathrm{Cl}^{*}+\mathrm{O}_{2}
\end{aligned}
$$

Net: $\mathrm{O}+\mathrm{O}_{3}=2 \mathrm{O}_{2(\mathrm{~g})}$

\section{EFFECTS OF OZON}
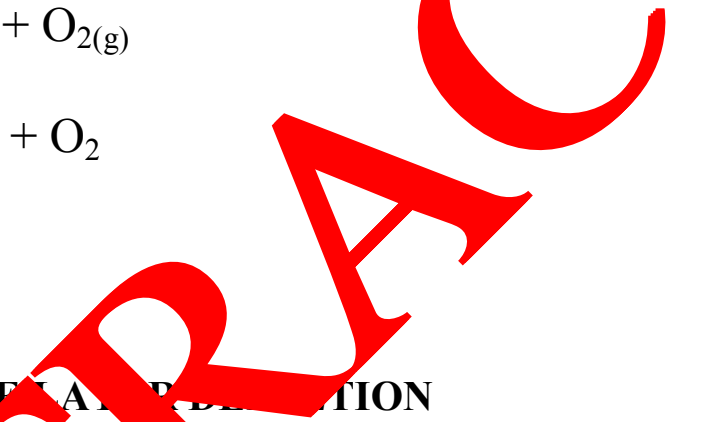

Correlation bet $\mathrm{e}$, he attend $/$ increase in UV-B and estimated ozone loss may affect rate of skin an er. E. uggested that every $1 \%$ decrease of ozone column will result in $3 \%$ rise in cidence of no clanoma. Besides, enhanced levels of UV-B has the direct harmful effer on ho ins in the following ways below:

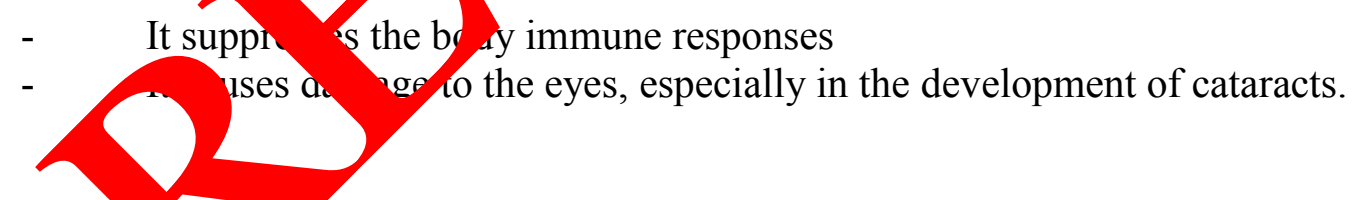

\section{TE TSTIAL PLANTS}

Plants are mostly adapted to some level of visible radiation. But two thirds have been found to be sensitive to UV-B radiation (Narayanan, 2009) sensitive plants show reduced growth and smaller leaves unable to photosynthesize as efficient as others. Such plants are affected as

- $\quad$ They yield small amount of seeds or fruits

- $\quad$ They show changes in chemical composition, which affects food quality

- $\quad$ Upset the delicate balance in natural ecosystem thus changing the dissolution and balance of plants. 


\section{CLIMATE}

Ozone cycles through its round of creation and destruction. The overall absorption of radiations is dumped as heat in the stratosphere. Any depletion of stratospheric ozone is predicted to cool the region, hence changes the temperature structure of the atmosphere to some extent.

\section{CONCLUSION}

Natural and anthropogenic activities on earth are constantly emitting $c^{\prime}$ nical was into the atmosphere. These chemical wastes in the atmosphere undergo vario chemic processes that tent to produce intermediates that ultimately lead to Lone form on destruction. Ozone molecule in the atmosphere no doubt serves the $p$ ose 9 lanke, g the earth surface from the harmful effects UV radiations. However, it tep 1 throu various chemical process stated in this study, has greatly impacted ne atively or umar, animals, plants and climate. The understanding of the source of che in wastes the cestroy ozone layer and cascade of chemical processes involved in o one letion become apt and imperative in the choice of technologies to be emplopean monito and remediation of atmosphere ozone depletion.

\section{References}

[1] Bhatia S. C., Environmental Chemistry. C BS an er, New Delhi, 2006.

[2] Bridgman H., Global Air Poll probl ms for the 1990s. New York. Belhaven Press, 1991.

[3] O’Neal P., Environmer Chedn), (1983).

[4] Santra S. C., Envir ental Scie, New central book publisher (p) Ltd. Kolkara, 2012.

[5] Singer S. F. (ed. Glob ffects of Environmental Pollution. Springer Verlag. New

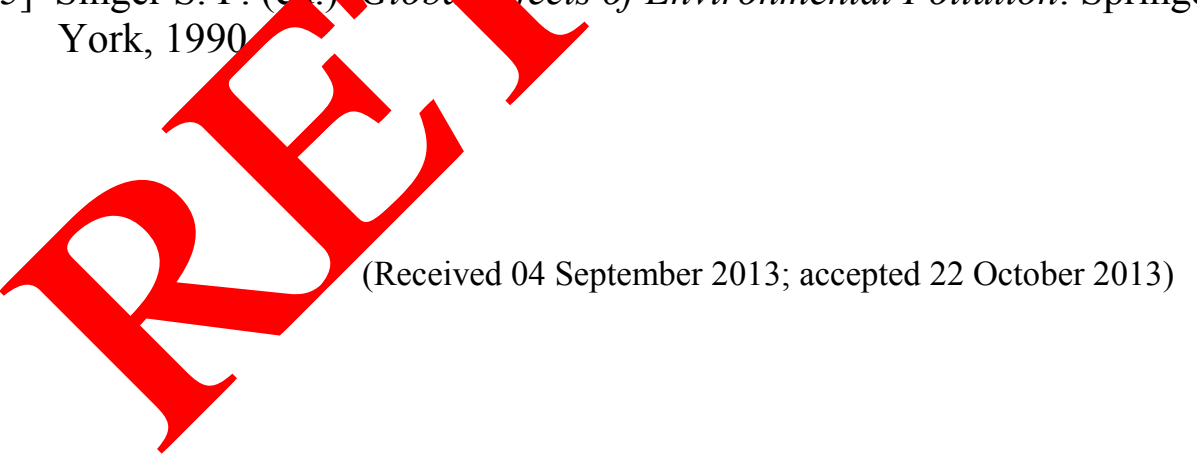

